\title{
THE ASSOCIATION BETWEEN DEPRESSION AND ANXIETY SYMPTOMS WITH SIX CORE COMPONENTS OF SOCIAL NETWORKING SITES ADDICTION: A CROSS-SECTIONAL STUDY IN SERBIA
}

\author{
Tamara Jovanović1,2, Aleksandar Višnjić1,2, Marko Gmijović3
}

\begin{abstract}
It would seem that today the most important thing for many individuals is to have a good profile picture on online social networks. Accordingly, there is a serious possibility that addiction to social networking sites (SNS) can lead to psychosocial and mental disorders and other negative consequences on health-related issues. So, the aim of this study was to determine the association between the excessive use of social networking sites with the symptoms of depression and anxiety.

This cross-sectional study was carried out at the University of Niš, Faculty of Medicine (Serbia) from September to December 2019. The study included 1,405 participants and all of them were assessed by using an appropriate questionnaire. The statistical analysis of the data included the binary logistic regression.

The strongest predictor of whether one has high levels of depression symptoms was the state of conflict where the odds ratio (OR) was 10.28 (95\% CI: $5.84-18.08$ ). It has been observed that depression symptoms are also more common in those respondents with expressed withdrawal symptoms (OR $=4.27,95 \% \mathrm{CI}: 3.04-6.00)$, and with mood modification (OR $=1.82,95 \% \mathrm{CI}: 1.12-2.96)$. Anxiety symptoms, similar to those of depression, are most present in individuals with conflict state (OR $=10.31,95 \% \mathrm{CI}$ : $5.25-$ 20.26), in those with withdrawal symptoms (OR $=6.83,95 \% \mathrm{CI}: 4.98-9.38$ ), and then with mood modification (OR $=2.55,95 \% \mathrm{CI}: 1.60-4.07)$. The number of active accounts/profiles and number of devices, as well as state of salience and tolerance played no part in any of the cases.

This study has shown a direct link between excessive SNS use and depression and anxiety symptoms. Further detailed research, especially longitudinal studies, is needed to understand the essential nature of these links. In any case, public health professionals should draw the attention of people, especially the younger population, in terms of limiting the use of social networks.
\end{abstract}

Acta Medica Medianae 2021;60(1):28-37.

Key words: online social networking, addiction, depression, anxiety

${ }^{1}$ University of Niš, Faculty of Medicine, Niš, Serbia

${ }^{2}$ Institute of Public Health Niš, Niš, Serbia

${ }^{3}$ Digestive Surgery Clinic, Clinical Center of Niš, Niš, Serbia

Contact: Tamara Jovanović

48 Dr Zoran Djindjić Blvd., 18000 Niš, Serbia

E-mail: tamara.rangelov@gmail.com

\section{Introduction}

The area of social network sites (SNS) addiction is still under-explored. There are more and more of these networks (with new ones constantly emerging), and everything is directed towards making life happening through them. Thus, the era we live in is one of digitized reality, with much controversy. A good deal of the human population has opted to interact via Facebook, Instagram, YouTube, Twitter, Snapchat, Tinder, LinkedIn, WhatsApp, and other social networks. The power of social networking is such that the number of worldwide users is expected to reach some 4 billion monthly active social media users by 2021, around a half of Earth's entire population, and especially increasing by mobile phone active users $(1,2)$.

Changes in lifestyle in the $21^{\text {st }}$ century carry the most turbulent possible performance, which a modern human, possessed by a marvelous conglomerate of external and internal pressures, is definitely unable to convey in a non-neurotic way. The great geostrategic changes of the late 1980s, the sexual revolution of the 1960s, the technological 
revolution, but also the most current, information technology one, led to evident new possibilities in civilization prosperity, but also left the individual confused, unprepared to psychologically follow the entirety of the grandiose changes. The individual, as well as any possibility of forming mature, meaningful relationships and partnerships are endangered. People are becoming increasingly more lonely, increasingly alienated from their environment, family, society, from themselves.

Such circumstances become a fantastic ambience of a whole range of addictions - from old preexisting (alcohol, psychoactive substances, gambling), through trivial ones (dependence on work, parents, on partners in passive-dependent and symbiotic relationships), and to those produced by modern times and the modern-day lifestyle (social networks, internet, mobile phones, television). So, many times, and especially among young people (which is the experience of the authors), it would appear that the most important thing today is to have a good profile picture.

The symptoms of problematic SNS use are similar to symptoms of substance use and behavioral addictive disorders (3). A recent study revealed a bidirectional association between SNS and depression among adolescents, meaning that depression significantly contributes to the development of SNS addiction, and in turn, depressed individuals experience more deleterious effects from addictive online social networking use (4). Also, another study has showed that initial levels of social media use to alleviate boredom were associated with problematic social networking site use, financial stress, anxiety, and empathy (5).

There is evidence from several empirical studies demonstrating that SNS usage can contribute to psychosocial and behavioral disorders and other negative consequences on health-related issues as well (6-13). Some of these studies have also reported high prevalence rates of problematic SNS use or even of SNS addiction among the human population worldwide (7-8, 13-15).

It is particularly debatable where to draw the boundary - between excessive use, i.e. diagnosis of SNS addiction, and normal use (16-19). In doing so, the main question is whether addiction or overuse of these networks can trigger some mental disorders, or whether they are merely concealed through them (such as obsessive-compulsive disorder).

A new version of ICD (International Classification of Diseases) was released by WHO in 2018 to allow Member States to prepare for implementation, and start reporting using ICD-11 in January 2022 $(20,21)$. According to this proposal, SNS addiction could be classified merely as a "6C51.0 Gaming disorder, predominantly online" under "Disorders due to addictive behaviors" (20). The situation is much the same with the criteria of the fifth edition of the Diagnostic and Statistical Manual of Mental Disorders (DSM-5) (22). Although gambling disorder is currently the only behavioral addiction officially recognized by the American Psychiatric Association, Internet gaming disorder has been added to section III of the fifth edition of the Diagnostic and Statistical Manual of Mental Disorders (DSM-5) as a tentative disorder, further underscoring the potential negative impact of specific Internet-related activities (22).

So far, according to ICD-10, only "F10.2. Syndroma dependentiae" exists as a formal diagnosis. However, SNS addiction is a broadly accepted term among health professionals and researchers. It certainly refers to the excessive use of SNSs, which can lead to decreased job or academic performance, absence, relationship problems, diminished social activities, and an adverse influence on psychological well-being. There is also a definition of addiction adopted by the American Society of Addiction Medicine (ASAM) Board of Directors in 2019: "Addiction is a treatable, chronic medical disease involving complex interactions among brain circuits, genetics, the environment, and an individual's life experiences. People with addiction use substances or engage in behaviors that become compulsive and often continue despite harmful consequences. Prevention efforts and treatment approaches for addiction are generally as successful as those for other chronic diseases" (23).

Hence in our study we try to examine, precisely by using online social networks, the degree of dependence on SNS within the framework of the latest theoretical findings, and with particular emphasis on its association with mental health, that is, symptoms of depression and anxiety. As mentioned earlier, SNS use has become widespread particularly among the youth. The present study was aimed at understanding the existing pattern of SNS use and estimating the prevalence of depression and anxiety among the excessive users. The main question is whether the behavior of SNS overuse fulfills the definition of addiction. On the basis of the above discussion, the following research question is addressed:

Is there a significant association between overuse of SNS and mental health in terms of elevated levels of depression and anxiety symptoms?

\section{Methods}

\section{Participants}

This cross-sectional study was carried out at the University of Niš, Faculty of Medicine (Serbia) from September to December 2019. All of the participants were assessed by using standardized questionnaires. The study included 1,405 randomly selected respondents (688 males and 717 females). A total of 1,550 of participants were invited, and $1,405(90.64 \%)$ of them responded.

\section{Procedure}

The study was first performed by uploading an electronic version of the questionnaire to the authors' Facebook profiles, with a brief explanation of what it was and for what purpose it would be used. The authors then, via Facebook, where they 
themselves had accounts, personally invited randomly selected 1,550 people from Serbia to complete the questionnaire. By clicking on the link, respondents would automatically access the questionnaire.

Symptoms of social networking sites addiction involved six core components and were assessed using a modified version of the Bergen Facebook Addiction Scale (BFAS) so that it applied to all social networks and was adapted for use in the Serbian language (24). Symptoms of depression and anxiety were assessed using the Depression Anxiety Stress Scale (DASS 42), a device for measuring psychological health $(25,26)$.

The participants also reported their socioeconomic characteristics. They were also asked "On how many social networks do you have active accounts/profiles? (Facebook, Instagram, Twitter, Pinterest, Snapchat, WhatsApp, Tumblr, Youtube...)", and "How many different devices do you use to access these profiles (a home computer, laptop, mobile phone, tablet, workplace computer)?"

Questionnaire completion took approximately 15 minutes. Only fully completed questionnaires were returned to the authors.

\section{Measures}

To measure SNS addiction, the authors decided to use the Bergen Facebook Addiction Scale (BFAS), which was modified so that it applied to all social networks and was adjusted to suit the needs of the Serbian language. The BFAS comprises six items covering the core features of behavioral addictions, measured by a five-point Likert scale ( $1=$ very rarely or never, $2=$ rarely, $3=$ some-times, 4 = often, 5 = very often), concerning experi-ences during the past year related to Facebook use (24, 27). These 6 items reflect the six core elements of addiction: salience, tolerance, mood modification, relapse, withdrawal symptoms, and conflict:

(1) Salience - the activity that become the most important in one's life and dominates one's thinking, feelings, and behavior;

(2) Tolerance - increasing amounts of the activity are required to achieve previous effects;

(3) Mood modification - the activity modifies mood;

(4) Relapse - a tendency to revert to earlier patterns of the activity after absti-nence or control;

(5) Withdrawal - the occurrence of un-pleasant feelings when the activity is discontinued or suddenly reduced; and

(6) Conflict - the activity causes conflicts in relationships, in work/education, and other activities. The reliability score of the BFAS in terms of Cronbach's alpha rates this scale at 0.83 .

The DASS 42 is a set of three self-reporting scales designed to measure the negative emotional states of depression, anxiety, and stress. Each of the three scales contains 14 items divided into subscales of $2-5$ items with similar content $(25,26)$. The respondents were asked to mark from 0 (none) to 3 (mostly or almost always) the extent to which they experienced each of the listed conditions during the previous week. The score results of depression and anxiety were calculated by adding the points for each relevant scale. The result was then calculated for every respondent and for each of the subscales, according to the score matrix, and then evaluated as per the severity-rating index. The reliability scores in terms of Cronbach's alpha rate the depression scale at 0.91 , and the anxiety scale at 0.84 .

\section{Statistical Analysis}

The statistical analysis was performed using the SPSS 17.0 program (SPSS Inc., Chicago, IL, USA) in Windows 7 Ultimate. The research results were presented in table form.

The statistical analysis of the data included the application of descriptive tests and analytical parametric tests, as well as binary logistic regression tests. Descriptive statistics were calculated to report the analyses of the data that were presented as mean and standard deviations, median and mode. The categorical variables were shown as frequency and percentages. The independent t-test was used to compare the parametric variables between the genders. Pearson and Spearman correlation tests were used to determine the strength of the relationships between some general characteristics of the surveyed participants and 6 core components of SNS addiction. A binary logistic regression was used to estimate the odds ratios (ORs) and 95\% confidence intervals (CIs) of the independent and interactive relationships between several prediction variables, such as the number of active accounts/profiles, number of devices, and six core elements of addiction (salience, tolerance, mood modification, relapse, withdrawal symptoms, and conflict) and depression and anxiety. The statistical significance was set at $p<0.05$.

\section{Ethics}

The study procedures were carried out in accordance with the Declaration of Helsinki, and the approval of the Ethical Committee of the Faculty of Medicine, University of Niš. All participants were informed about the study, and all provided informed consent via online system.

\section{Results}

The study included 1,405 participants, 688 males (48.97\%) and 717 females (51.03\%). Participants' ages ranged from 19 to 69 years (Mean = 34.77, SD = 8.12); with a median, as well as a mode of 35 .

An independent samples t-test showed a significant age difference between the women ( $M=$ 33.68, $\mathrm{SD}=7.41)$ and men $(\mathrm{M}=37.41, \mathrm{SD}=$ 9.10); $\mathrm{t}(1403)=-8.00, \mathrm{p}<0.001$. However, the difference between the mean values (Mean difference $=-3.73,95 \% \mathrm{CI}:-4.64$ to -2.81 ) was very small (eta squared $=0.043$ ).

Of the 1,405 respondents, 289 (20.6\%) only had a high school education, 158 of them (11.2\%) had some higher education, and as many as 958 
(68.2\%) had graduated at or are currently attending university.

Four or more active accounts/profiles on online social networks have 421 (30\%) respondents, and four or more different devices (a home computer, laptop, mobile phone, tablet, workplace computer) are used to access these profiles by 114 $(8.11 \%)$ of them (Table 1$)$.

Table 1. Active accounts/profiles and devices with Internet connection of participants

\begin{tabular}{||c|cccccc||}
\cline { 2 - 6 } \multicolumn{1}{c|}{} & $\mathrm{n}$ & $\%$ & Mean & SD & Median & Mode \\
\hline Number of active accounts/profiles & & & 2.91 & 1.56 & 3 & 2 \\
1 & 266 & 18.9 & & & & \\
3 & 400 & 28.5 & & & & \\
4 and more & 318 & 22.6 & & & & \\
Number of active devices & 421 & 30.0 & & & & \\
1 & & & 2.16 & 1.03 & 2 & \\
2 & 344 & 24.5 & & & & \\
3 & 687 & 48.9 & & & & \\
4 and more & 260 & 18.5 & & & & \\
\hline
\end{tabular}

\section{The scores of the BFAS}

The respondents' answers to five standard offered Likert scale questions are shown in Table 2.

When we consider only answers "Often" and "Very often" in order to approach SNS addiction in a more measurable way for these 6 core components, then we get that Salience was present in 213 participants (15.2\%), Tolerance in 192 (13.7\%), Mood modification in 111 (7.9\%), Relapse in 231 (16.4\%), Withdrawal symptoms in 281 (20.0\%), and Conflict in 75 participants (5.3\%).

Table 2. BFAS questions

\begin{tabular}{|c|c|c|c|c|c|}
\hline BFAS questions & $\begin{array}{c}\text { Very rarely } \\
\text { or never } \\
\text { n (\%) } \\
\end{array}$ & $\begin{array}{l}\text { Rarely } \\
\text { n (\%) }\end{array}$ & $\begin{array}{c}\text { Sometimes } \\
\text { n (\%) }\end{array}$ & $\begin{array}{l}\text { Often } \\
\text { n (\%) }\end{array}$ & $\begin{array}{c}\text { Very often } \\
\text { n (\%) }\end{array}$ \\
\hline Item 1 Salience & $\begin{array}{c}320 \\
(22.8) \\
\end{array}$ & $\begin{array}{c}476 \\
(33.9) \\
\end{array}$ & $\begin{array}{c}396 \\
(28.2)\end{array}$ & $\begin{array}{c}183 \\
(13.0) \\
\end{array}$ & $\begin{array}{c}30 \\
(2.1) \\
\end{array}$ \\
\hline Item 2 Tolerance & $\begin{array}{c}249 \\
(17.7) \\
\end{array}$ & $\begin{array}{c}495 \\
(35.2) \\
\end{array}$ & $\begin{array}{c}469 \\
(33.4) \\
\end{array}$ & $\begin{array}{c}150 \\
(10.7) \\
\end{array}$ & $\begin{array}{c}42 \\
(3.0) \\
\end{array}$ \\
\hline Item 3 Mood modification & $\begin{array}{c}474 \\
(33.7)\end{array}$ & $\begin{array}{c}473 \\
(33.7)\end{array}$ & $\begin{array}{c}347 \\
(24.7)\end{array}$ & $\begin{array}{c}69 \\
(4.9) \\
\end{array}$ & $\begin{array}{c}42 \\
(3.0) \\
\end{array}$ \\
\hline Item 4 Relapse & $\begin{array}{c}410 \\
(29.2)\end{array}$ & $\begin{array}{c}403 \\
(28.7)\end{array}$ & $\begin{array}{c}361 \\
(25.7) \\
\end{array}$ & $\begin{array}{c}189 \\
(13.5)\end{array}$ & $\begin{array}{c}42 \\
(3.0) \\
\end{array}$ \\
\hline Item 5 Withdrawal symptoms & $\begin{array}{c}502 \\
(35.7) \\
\end{array}$ & $\begin{array}{c}436 \\
(31.0) \\
\end{array}$ & $\begin{array}{c}186 \\
(13.2)\end{array}$ & $\begin{array}{c}230 \\
(16.4)\end{array}$ & $\begin{array}{c}51 \\
(3.6) \\
\end{array}$ \\
\hline Item 6 Conflict & $\begin{array}{c}773 \\
(55.0) \\
\end{array}$ & $\begin{array}{c}380 \\
(27.0) \\
\end{array}$ & $\begin{array}{c}177 \\
(12.6) \\
\end{array}$ & $\begin{array}{c}63 \\
(4.5)\end{array}$ & $\begin{array}{c}12 \\
(0.9) \\
\end{array}$ \\
\hline
\end{tabular}

Salience BFASQ 1 - I spend a lot of time thinking about social networks, what I am missing when I do not use them, or plan how I will use them;

Tolerance BFASQ 2 - I feel an overwhelming need to use social networks more and more;

Mood modification BFASQ 3 - I use social networks to escape from personal problems or to repair a bad mood;

Relapse BFASQ 4 - When I try to cut down the time spent on social networks, I fail;

Withdrawal symptoms BFASQ 5 - I become restless/anxious or disturbed if I am denied or abruptly cut off from social networks;

Conflict BFASQ 6 - I happen to use social networks to the extent that it adversely affects my job/ schooling (poor performance, poor concentration) or relationships with people (lie or argue in defense regarding the amount of time spent on or the way social networks are used). 
The associations between some general characteristics of the surveyed participants and the 6 components of SNS addiction were examined by a Pearson correlation coefficient (i.e., by Spearman's rho rank correlation coefficient). Preliminary analyses were conducted in order to check the assumptions of normality, linearity, and homogeneity of the variants. The following correlations were calculi (Table 3):

It was found that only the Education level of the participants was significantly associated with almost all of the six core components of SNS addiction ( $p<0.001$ ), except for the Mood modification.

Table 3. Correlations between certain characteristics and 6 components of SNS addiction

\begin{tabular}{|c|c|c|c|c|c|c|}
\hline & Salience & Tolerance & $\begin{array}{c}\text { Mood } \\
\text { modification }\end{array}$ & Relapse & $\begin{array}{l}\text { Withdrawal } \\
\text { symptoms }\end{array}$ & Conflict \\
\hline Age & -.040 & -.017 & .010 & -.049 & -.052 & -.008 \\
\hline$p$ & .137 & .514 & .712 & .066 & .053 & .760 \\
\hline $\begin{array}{c}\text { Number of active } \\
\text { profiles }\end{array}$ & .022 & -.020 & -.001 & .018 & -.010 & .007 \\
\hline$p$ & .410 & .443 & .978 & .493 & .708 & .793 \\
\hline $\begin{array}{c}\text { Number of active } \\
\text { devices }\end{array}$ & -.005 & -.025 & -.006 & .027 & -.020 & -.006 \\
\hline$p$ & .848 & .353 & .808 & .312 & .461 & .831 \\
\hline Sex & .042 & .013 & .003 & $-.053^{*}$ & .031 & -.013 \\
\hline$p$ & .113 & .629 & .908 & .047 & .253 & .613 \\
\hline Education level & $-.087^{* *}$ & $-.078^{* *}$ & -.045 & $-.088^{* *}$ & $-.095^{* *}$ & $-.105^{* *}$ \\
\hline$p$ & .001 & .003 & .092 & .001 & .000 & .000 \\
\hline
\end{tabular}

** Correlation is significant at the 0.01 level, and * at the 0.05 level.

Table 4. The scores of depression, and anxiety with respect to participants' gender

\begin{tabular}{|c||ccc||ccc||}
\hline \multirow{3}{*}{ Symptom Levels } & \multicolumn{3}{|c|}{ Depression } & \multicolumn{3}{c||}{ Anxiety } \\
\cline { 2 - 7 } & \multirow{2}{*}{ Total } & Male & Female & Total & Male & Female \\
& & $\mathrm{n} \%$ & $\mathrm{n} \%$ & & $\mathrm{n} \%$ & $\mathrm{n} \%$ \\
\hline \multirow{2}{*}{ Normal } & $\mathrm{n}=1.022$ & 498 & 523 & $\mathrm{n}=883$ & 507 & 419 \\
& $72.7 \%$ & 72.3 & 72.9 & $62.8 \%$ & 73.7 & 58.4 \\
\hline \multirow{2}{*}{ Mild } & $\mathrm{n}=132$ & 85 & 59 & $\mathrm{n}=90$ & 35 & 50 \\
& $9.4 \%$ & 12.4 & 8.2 & $6.5 \%$ & 5.1 & 6.9 \\
\hline \multirow{2}{*}{ Moderate } & $\mathrm{n}=137$ & 85 & 62 & $\mathrm{n}=234$ & 105 & 123 \\
& $9.8 \%$ & 12.4 & 8.7 & $16.7 \%$ & 15.3 & 17.2 \\
\hline \multirow{2}{*}{ Severe } & $\mathrm{n}=69$ & 15 & 43 & $\mathrm{n}=99$ & 31 & 58 \\
& $4.9 \%$ & 2.2 & 6.0 & $7.0 \%$ & 4.5 & 8.1 \\
\hline \multirow{2}{*}{ Extremely severe } & $\mathrm{n}=45$ & 5 & 30 & $\mathrm{n}=99$ & 10 & 67 \\
& $3.2 \%$ & 0.7 & 4.2 & $7.0 \%$ & 1.4 & 9.4 \\
\hline
\end{tabular}

Levels of depression: normal (0-9), mild (10-13), moderate (14-20), severe (21-27), extreme severe (28+); 
Levels of anxiety: normal (0-7), mild (8-9), moderate (10-14), severe (15-19), extreme severe (20+).

The scores of depression and anxiety (DASS42)

Moderate, severe, or extremely severe levels of depression symptoms were reported by 251 respondents $(17.9 \%)$ and "above mild" anxiety symptoms were reported by 432 (30.7\%) respondents (Table 4).

Prediction of the Levels of Depression and Anxiety Based on the Parameters Related to the Social Networking Sites Addiction

A binary logistic regression was conducted in order to estimate the effects of several factors on the probability that the participants would respond positively to questions about depression and anxiety. First, in SPSS we selected the "transform variable" into two answers option, classifying the scores on the DASS 42 into two categories, whereby the answers "normal" and "mild" were classified as NO, and the remaining three (moderate, severe, and extremely severe) were classified as YES.

Then, similarly, the 6 components of SNS addiction were binary regrouped (only answers "often" and "very often" were classified as YES). The model (a group of prediction variables - how well it predicts or explains the "outcome") contains 8 independent variables: the number of active accounts/profiles, number of devices, salience, tolerance, mood modification, relapse, withdrawal symptoms, and conflict. The whole model (along with all the predictors) was statistically significant, namely: for depression: $\chi^{2}(8, \mathrm{~N}=1405)=209.271, \mathrm{p}<0.001$; for anxiety: $\chi^{2}(8, \mathrm{~N}=1405)=306.641, \mathrm{p}<0.001$. This indicates that the model distinguishes between those respondents who are, and those who are not sorted, so that they have some of the symptoms. The model explains between $13.8 \%$ ( $r^{2}$ Cox and Snell) and $22.7 \%$ ( $r^{2}$ Nagelkerke) of the variance in the existence of depression symptoms, and between 19.6\% ( $r^{2}$ Cox and Snell) and 27.7\% ( $r^{2}$ Nagelkerke) of the variance in the existence of anxiety symptoms. The assumptions of collinearity and singularity were satisfied, and non-typical points were also checked.

Table 5. Prediction of depression and anxiety symptoms related to the parameters of SNS addiction

\begin{tabular}{|c|c|c|c|c|c|c|}
\hline \multirow{2}{*}{ Independent Variables } & \multirow{2}{*}{ B } & \multirow{2}{*}{ df } & \multirow{2}{*}{$\mathbf{p}$} & \multirow{2}{*}{ OR } & \multicolumn{2}{|c|}{ 95\% CI for OR } \\
\hline & & & & & Lower & Upper \\
\hline Depression & \multicolumn{6}{|c|}{ Hosmer-Lemeshow test of goodness-of-fit $\left(p=0.730\right.$, for $\left.\chi^{2}=4.426, \mathrm{df}=7\right)$} \\
\hline Number of profiles & -0.001 & 1 & 0.977 & 0.999 & 0.903 & 1.104 \\
\hline Number of devices & 0.013 & 1 & 0.868 & 1.013 & 0.872 & 1.177 \\
\hline BFASQ 1(1) & 0.220 & 1 & 0.323 & 1.246 & 0.806 & 1.927 \\
\hline BFASQ 2(1) & -0.336 & 1 & 0.178 & 0.715 & 0.439 & 1.165 \\
\hline BFASQ 3(1) & 0.599 & 1 & 0.016 & 1.820 & 1.117 & 2.965 \\
\hline BFASQ 4(1) & 0.397 & 1 & 0.044 & 1.487 & 1.010 & 2.191 \\
\hline BFASQ 5(1) & 1.452 & 1 & $<0.001$ & 4.270 & 3.042 & 5.993 \\
\hline BFASQ 6(1) & 2.330 & 1 & $<0.001$ & 10.275 & 5.841 & 18.075 \\
\hline Constant & -2.280 & 1 & $<0.001$ & 0.102 & \multicolumn{2}{|c|}{ Correctly classified $84.3 \%$} \\
\hline Anxiety & \multicolumn{6}{|c|}{ Hosmer-Lemeshow test of goodness-of-fit $\left(p=0.635\right.$, for $\left.\chi^{2}=6.106, \mathrm{df}=8\right)$} \\
\hline Number of profiles & -0.061 & 1 & 0.169 & 0.941 & 0.863 & 1.026 \\
\hline Number of devices & -0.005 & 1 & 0.935 & 0.995 & 0.873 & 1.133 \\
\hline BFASQ 1(1) & -0.025 & 1 & 0.905 & 0.975 & 0.649 & 1.466 \\
\hline BFASQ 2(1) & 0.094 & 1 & 0.658 & 1.099 & 0.725 & 1.666 \\
\hline BFASQ 3(1) & 0.937 & 1 & 0.000 & 2.553 & 1.601 & 4.071 \\
\hline BFASQ 4(1) & 0.138 & 1 & 0.434 & 1.149 & 0.812 & 1.625 \\
\hline BFASQ 5(1) & 1.922 & 1 & $<0.001$ & 6.832 & 4.978 & 9.375 \\
\hline BFASQ 6(1) & 2.333 & 1 & $<0.001$ & 10.314 & 5.251 & 20.258 \\
\hline Constant & -1.315 & 1 & $<0.001$ & 0.268 & \multicolumn{2}{|c|}{ Correctly classified $78.5 \%$} \\
\hline
\end{tabular}

B - coefficient for the constant ("intercept") in the null model; OR - odds ratio; CI - Confidence interval.

As Table 5 shows, four independent variables (mood modification, relapse, withdrawal symptoms, and conflict) provided a unique statistically significant contribution to some of the two presented models. The strongest predictor of whether a respondent had high levels of depression symptoms was conflict state, where the odds ratio was $\mathrm{OR}=$ 10.28. This shows that respondents with higher 
scores of a conflict component have symptoms of depression 10.28 times more often, with all the other factors in the model being equal. Also, it has been observed that depression symptoms are more common in those respondents with expressed withdrawal symptoms (OR $=4.27)$, followed by mood modification $(\mathrm{OR}=1.82)$, and with relapse $(\mathrm{OR}=$ 1.49).

Anxiety symptoms, similar to depression ones, are most present in those respondents with conflict state $(\mathrm{OR}=10.31)$, in those with withdrawal symptoms (OR $=6.83$ ), and then with mood modification $(O R=2.55)$. The number of active accounts/profiles and number of devices, as well as salience and tolerance, played no part in any of the cases.

\section{Discussion}

Of all 6 core components of SNS addiction, the highest prevalence was $20.0 \%$ for withdrawal symptoms. Symptoms of depression and anxiety were 4.3 times and 6.8 times greater, respectively, in those who were addicted, according to the expressed withdrawal symptoms. The prevalence among our respondents of measured higher values of the relapse state was $16.4 \%$ and of the mood modification state was $7.9 \%$. Moderate, severe, or extremely severe levels of depression and anxiety symptoms were reported by $17.9 \%$ of the respondents and by $30.7 \%$ of the respondents, respectively. Symptoms of depression were 1.5 times greater in relapse symptoms and 1.8 times greater in those who were "addicted" according to expressed mood modification symptoms, and anxiety symptoms were 2.5 times greater for the mood modification state. Although state of conflict showed the lowest prevalence rate $(5.3 \%)$ compared to all the studied parameters, symptoms of depression and anxiety were most pronounced in the conflict state about ten times greater in those who were "addicted" according to them.

One of the problems the authors were most concerned with was how to measure addiction. Five standard offered Likert-type scale answers from the lowest to the highest, with the recommendation that the "medium" answer be considered (a liberal and a more conservative approach) (24), did not seem realistic to us. So, we raised the threshold for determining addiction. We decided to approach the BFAS in a more practical way, by taking into account only answers "4" and "5" ("often" and "very often") to each of the six asked questions. We also concluded that we could not, like for DASS 42, summarize the points altogether on some indirect questions to get the final scores that could determine the degree of addiction. So, in the end, we decided to set some kind of "diagnosis" of the addiction, for the purposes of our research, by adding a dependency property to each of the 6 components if the values on the scale were "often" and "very often" (overuse). In such a way it does not necessarily correlate with the other five components. Unfortunately, because with the existing instruments we cannot precisely measure SNS addiction, nor can we even classify it as such $(21,22)$, we can only consider the "reasonable suspicion of possibility" of being addicted.

According to this study, SNS addiction contributed to psychosocial disorders, increasing levels of depression and anxiety in the respondents. This finding supports previous researches $(16,20,27-$ 31). The conceptualization of SNS addiction as a primary or secondary disorder is also in agreement with the findings from some previous research papers $(19,32-34)$. Mental health professionals should use these findings to develop intervention programs focused on improving the respondents' well-being. For example, from a psychoanalytic point of view, each addiction has its matrix, but also causal overcompensation for a deep sense of loneliness and fear of loss. Often the cause may be the revitalization of the pattern we grew up with. It is characteristic that many addictions go hand in hand, or transform at different stages of life, and change. Cultural environments and aesthetics of living also initiate the content of addiction.

Social network dependency, i.e. addiction, is more specific, as it floods the broader generational, intellectual, and social spectrum and creates a pattern by default, which becomes an automated, almost obsessive-compulsive form. What binds it to the classic forms of addiction is the aforementioned neurotic spectrum of symptomatology, but also a lifestyle that moves further away from that of the everyday, authentic, and leads to the creation of another, more secluded, often unreal, virtual reality.

However, these findings certainly require additional research, although other researchers have also reported that SNS addiction can influence the development of psychiatric disorders; it should be noted that the evidence of a true nature of a strong link between mental health disorders, and social network dependence, remains unclear $(20,33,35$, 36).

This is also supported by the findings of the study done among Indian students, which reported using of Internet more for social networking such as making new friends online or getting into relationships online were risk factors associated with Internet addiction (37). The students on average reported spending $3.47 \mathrm{~h} /$ day online, with about twothirds of them using the Internet mainly for social networking. The main device used for accessing SNS was mobile phone for more than three-fourths of students. Physical impairments in the form of insomnia $(26.8 \%)$, day time sleepiness $(20 \%)$, and eye strain $(19 \%)$ were also reported among problem users. In addition, it suggests that the use of SNS might be associated with faulty cognitions such as "Internet being a safe way of presenting oneself to others", or a coping behavior for alleviating low or dysphoric mood (37).

More than half of individuals aged 16-74 used the Internet for social networking sites, and this percentage especially increases among the younger generations (38). Social networking sites have become socialization tools that allow reaching information and establishing networks with certain orientation toward achieving specific goals (38).

The main strength of this study is its large sample size and to the best of our knowledge, this is 
the largest epidemiological study up-to-date on these issues in Serbia. Further, the study questionnaires were filled anonymously by the participants, which was done to encourage them to provide more truthful responses.

One of the limitations is that the questionnaires were distributed exclusively through social networks. Therefore, the questionnaires were filled out on a voluntary basis only by those who wanted and who were otherwise users of these networks. This could also be an explanation of why the number of females was higher than the number of males included in the study. In addition, depression and anxiety disorders, representing a global mental health concern, are highly comorbid and have shared symptoms and familial risk, and there is much higher prevalence in women (39-40). Also, self-report measures may lead to different response biases, such as social desirability, or memory recall.

\section{Conclusion}

There is no doubt that there is a direct link between SNS excessive use and depression and anxiety. While these links may not be explicitly cause-effect, there is a justified assumption that overuse of social networks exacerbates these symptoms. Strategies for self-control and limited SNS use should be developed by public mental health professionals. These strategies would be aimed at preventing the emergence of excessive SNS use among heavy users and could provide a way for them to cope with mental health disorders related to this.
The future will provide answers to both public health professionals and psychiatrists, psychologists, psychotherapists, regarding the direction of any measures taken to get out of such a "Pandora's box". Lifestyle balance and adjustments may be the conscious maneuver we will need. Before that, and certainly essential - is dealing with and recognizing the unconscious, essential sources of impulses that lead us to addiction. We must accept the fact that it is in the nature of people that adaptation to new concepts still has a time limit and that modern humans will enter a phase of more subtle and balanced interaction with what surrounds them. Until then, let us be aware that the new epoch, no matter how much we want it, also carries unprecedented mazes of danger. Additional researches, like longitudinal studies, are warranted for further confirmation of the findings from this study and to enhance our understanding about the same.

\section{Acknowledgments}

This work was supported by the Ministry of Science and Technological Development of the Republic of Serbia (Project 43012 and Project 41018).

Special thanks to Dr. Ivajlo Ilijev, a specialist of psychiatry and a psychotherapist.

\section{Conflicts of Interest}

The authors declare no conflict of interest.

\section{References}

1. Clement J. Social media - Statistics and facts. Statista May 2020 "cited 2020 October 5". Available from: URL: https://www.statista.com/topics/1164/socialnetworks/

2. Sanders I, Short CE, Bogomolova S, Stanford T, Plotnikoff R, Vandelanotte $C$, et al. Characteristics of Adopters of an Online Social Networking Physical Activity Mobile Phone App: Cluster Analysis. JMIR Mhealth Uhealth 2019;7(6):e12484.

[CrossRef][PubMed]

3. Meshi D, Ulusoy E, Özdem-Mertens C, Grady SM, Freestone DM, Eden A, et al. Problematic social media use is associated with increased risk-aversion after negative outcomes in the Balloon Analogue Risk Task. Psychol Addict Behav 2020;34(4):549-55. [CrossRef][PubMed]

4. Li JB, Mo PKH, Lau JTF, Su XF, Zhang X, Wu AMS, et al. Online social networking addiction and depression:
The results from a large-scale prospective cohort study in Chinese adolescents. J Behav Addict 2018; 7(3):686-96. [CrossRef][PubMed]

5. Stockdale LA, Coyne SM. Bored and online: Reasons for using social media, problematic social networking site use, and behavioral outcomes across the transition from adolescence to emerging adulthood. J Adolesc 2020;79:173-83. [CrossRef][PubMed]

6. Andreassen CS. Online social network site addiction: A comprehensive review. Curr Addict Rep 2015;2(2): 175-84. [CrossRef]

7. Bányai F, Zsila Á, Király O, Maraz A, Elekes Z, Griffiths $M D$, et al. Problematic social media use: Results from a large-scale nationally representative adolescent sample. PLoS One 2017;12(1):e0169839. [CrossRef][PubMed]

8. Cock RD, Vangeel J, Klein A, Minotte P, Rosas O, Meerkerk G. Compulsive use of social networking sites 
in Belgium: Prevalence, profile, and the role of attitude toward work and school. Cyberpsychol Behav Soc Netw 2014;17(3):166-71. [CrossRef][PubMed]

9. Morioka H, Itani O, Osaki Y, Higuchi S, Jike M, Kaneita $Y$, et al. Association between smoking and problematic Internet use among Japanese adolescents: Largescale nationwide epidemiological study. Cyberpsychol Behav Soc Netw 2016;19(9):557-61.

[CrossRef][PubMed]

10. Hormes JM. Under the influence of Facebook? Excess use of social networking sites and drinking motives, consequences, and attitudes in college students. J Behav Addict 2016;5(1):122-9. [CrossRef][PubMed]

11. Oberst U, Wegmann E, Stodt B, Brand M, Chamarro A. Negative consequences from heavy social networking in adolescents: The mediating role of fear of missing out. J Adolesc 2017;55:51-60. [CrossRef][PubMed]

12. Murray M, Maras D, Goldfield GS. Excessive Time on Social Networking Sites and Disordered Eating Behaviors Among Undergraduate Students: Appearance and Weight Esteem as Mediating Pathways. Cyberpsychol Behav Soc Netw 2016;19(12):709-15. [CrossRef][PubMed]

13. Tang CS, Koh YW, Gan Y. Addiction to Internet Use, Online Gaming, and Online Social Networking Among Young Adults in China, Singapore, and the United States. Asia Pac J Public Health 2017;29(8):673-82. [CrossRef][PubMed]

14. Ahmer Z, Tanzil S. Internet addiction among social networking sites users: Emerging mental health concern among medical undergraduates of Karachi. Pak J Med Sci 2018;34(6):1473-7.

[CrossRef][PubMed]

15. Jelenchick LA, Hawk ST, Moreno MA. Problematic internet use and social networking site use among Dutch adolescents. Int J Adolesc Med Health 2016; 28(1):119-21. [CrossRef][PubMed]

16. Biolcati R, Mancini G, Pupi V, Mugheddu V. Facebook Addiction: Onset Predictors. J Clin Med 2018;7(6): 118. [CrossRef][PubMed]

17. Xie W, Karan K. Predicting Facebook addiction and state anxiety without Facebook by gender, trait anxiety, Facebook intensity, and different Facebook activities. J Behav Addict 2019;8(1):79-87. [CrossRef][PubMed]

18. Pontes HM, Taylor M, Stavropoulos V. Beyond "Facebook Addiction": The Role of Cognitive-Related Factors and Psychiatric Distress in Social Networking Site Addiction. Cyberpsychol Behav Soc Netw 2018; 21(4):240-7. [CrossRef][PubMed]

19. Wegmann E, Oberst U, Stodt B, Brand M. Onlinespecific fear of missing out and Internet-use expectancies contribute to symptoms of Internet-communication disorder. Addict Behav Rep 2017;5:33-42. [CrossRef][PubMed]

20. World Health Organization. ICD-11 Revision. "cited 2020 October 5". Available from: https://icd.who.int/browse11/l-m/en

21. The L. Icd-11. Lancet 2019;393(10188):2275. [CrossRef]

22. Besser B, Loerbroks L, Bischof G, Bischof A, Rumpf HJ. Performance of the DSM-5-based criteria for Internet addiction: A factor analytical examination of three samples. J Behav Addict 2019;8(2):288-94. [CrossRef][PubMed]

23. American Society of Addiction Medicine. Definition of Addiction. 2019. "cited 2020 October 5". Available from: https://www.asam.org/resources/definition-ofaddiction
24. Andreassen CS, Torsheim T, Brunborg GS, Pallesen S. Development of a Facebook Addiction Scale. Psychol Rep 2012;110(2):501-17. [CrossRef][PubMed]

25. Crawford JR, Henry JD. The Depression Anxiety Stress Scales (DASS): Normative data and latent structure in a large non-clinical sample. Br J Clin Psychol 2003; 42:111-131. [CrossRef][PubMed]

26. Lovibond PH, Lovibond SH. Manual for the Depression Anxiety Stress Scales. $2^{\text {nd }}$ ed. Sydney, Australia: Psychology Foundation; 1995. [CrossRef]

27. da Veiga GF, Sotero L, Pontes HM et al. Emerging Adults and Facebook Use: the Validation of the Bergen Facebook Addiction Scale (BFAS). Int J Ment Health Addict 2019;17(2):279-94. [CrossRef]

28. Shaffer $\mathrm{HJ}$, LaPlante DA, LaBrie RA, Kidman RC, Donato AN, Stanton MV. Toward a syndrome model of addiction: Multiple expressions, common etiology. Harv Rev Psychiatry 2004;12(6):367-74. [CrossRef][PubMed]

29. Pantic I. Online social networking and mental health. Cyberpsychol Behav Soc Netw 2014;17(10):652-57. [CrossRef][PubMed]

30. Primack BA, Shensa A, Escobar-Viera CG, Barrett EL, Sidani JE, Colditz JB, et al. Use of multiple social media platforms and symptoms of depression and anxiety: A nationally-representative study among U.S. young adults. Comput Hum Behav 2017;69:1-9. [CrossRef]

31. Sampasa-Kanyinga $H$, Lewis RF. Frequent use of social networking sites is associated with poor psychological functioning among children and adolescents. Cyberpsychol Behav Soc Netw 2015;18(7): 380-5. [CrossRef][PubMed]

32. Snodgrass JG, Lacy MG, Dengah HJF II, Eisenhauer S, Batchelder G, Cookson RJ. A vacation from your mind: Problematic online gaming is a stress response. Comput Hum Behav 2014;38:248-60. [CrossRef]

33. Kardefelt-Winther D. Conceptualizing Internet use disorders: Addiction or coping process? Psychiatry Clin Neurosci 2016;71(7):459-66. [CrossRef][PubMed]

34. Thorens G, Achab S, Billieux J, Khazaal Y, Khan R, Pivin $E$, et al. Characteristics and treatment response of self-identified problematic Internet users in a behavioral addiction outpatient clinic. J Behav Addict 2014;3(1):78-81. [CrossRef][PubMed]

35. Salem AAMS, Almenaye NS, Andreassen CS. A psychometric evaluation of Bergen Facebook Addiction Scale (BFAS) of university students. IJPBS 2016;6: 199-205.

36. Zhang C, Brook JS, Leukefeld CG, Brook DW. Longitudinal psychosocial factors related to symptoms of Internet addiction among adults in early midlife. Addict Behav 2016;62:65-72. [CrossRef][PubMed]

37. Kumar S, Singh S, Singh K, Rajkumar S, Balhara YPS. Prevalence and pattern of problematic internet use among engineering students from different colleges in India. Indian J Psychiatry 2019;61(6):578-83. [CrossRef][PubMed]

38. de Mesa JC, Gómez-Jacinto L, Peláez LA, Erro-Garcés A. Social Networking Sites and Youth Transition: The Use of Facebook and Personal Well-Being of Social Work Young Graduates. Front Psychol 2020;11:230. [CrossRef][PubMed]

39. Altemus M., Sarvaiya N., Neill Epperson C. Sex differences in anxiety and depression clinical perspectives. Front Neuroendocrinol 2014;35(3):320-30. [CrossRef][PubMed]

40. Eid RS, Gobinath AR, Galea LAM. Sex differences in depression: Insights from clinical and preclinical studies. Prog Neurobiol 2019;176:86-102. [CrossRef][PubMed] 


\title{
POVEZANOST SIMPTOMA DEPRESIJE I ANKSIOZNOSTI SA ŠEST OSNOVNIH KOMPONENTI ZAVISNOSTI OD DRUŠTVENIH MREŽA: STUDIJA PRESEKA U SRBIJI
}

\author{
Tamara Jovanović1,2, Aleksandar Višnjić1,2, Marko Gmijović3 \\ ${ }^{1}$ Univerzitert u Nišu, Medicinski fakultet, Niš, Srbija \\ ${ }^{2}$ Institut za javno zdravlje Niš, Niš, Srbija \\ ${ }^{3}$ Klinika za digestivnu hirurgiju, Klinički centar Niš, Niš, Srbija
}

Kontakt: Tamara Jovanović

Bulevar dr Zorana Đinđića 48, 18000 Niš, Srbija

E-mail: tamara.rangelov@gmail.com

Čini se da je danas za mnoge najvažnije da imaju dobru profilnu sliku na društvenim mrežama. Shodno tome, postoji ozbiljna mogućnost da zavisnost od onlajn društvenih mreža može dovesti do psihosocijalnih i mentalnih poremećaja i drugih negativnih posledica u vezi sa zdravljem. Zato je cilj ove studije bio da se utvrdi veza između prekomerne upotrebe onlajn društvenih mreža sa simptomima depresije i anksioznosti.

Ova studija preseka sprovedena je na Univerzitetu u Nišu, na Medicinskom fakultetu (Srbija) od septembra do decembra 2019. godine. Studijom je obuhvaćeno 1.405 učesnika i svi su procenjeni pomoću odgovarajućeg upitnika. Statistička analiza podataka uključivala je binarnu logističku regresiju.

Najsnažniji prediktor za to da li neko ima visok nivo simptoma depresije bilo je stanje "sukoba", gde je odnos verovatnoće (OR) bio 10,28 (95\% CI: 5,84 - 18,08). Primećeno je to da su simptomi depresije takođe češći kod ispitanika sa izraženim simptomima "povlačenja" $(\mathrm{OR}=4,27 ; 95 \% \mathrm{CI}: 3,04-6,00)$ i sa "promenom raspoloženja" (OR = 1,82; 95\% CI: 1,12 - 2,96). Simptomi anksioznosti, slično kao kod depresije, najprisutniji su kod osoba sa konfliktnim stanjem (OR $=10,31 ; 95 \% \mathrm{CI}: 5,25-20,26)$, kod onih sa simptomima povlačenja (OR $=6,83$; $95 \% \mathrm{CI}: 4,98-9,38)$, a zatim i kod onih sa promenom raspoloženja (OR $=2,55 ; 95 \%$ CI: $1,60-4,07)$. Broj aktivnih naloga/profila i broj uređaja, kao i istaknutost $\mathrm{i}$ tolerancija nisu imali ulogu ni u jednom slučaju.

Ova studija pokazala je direktnu vezu između prekomerne upotrebe onlajn društvenih mreža i simptoma depresije i anksioznosti. Dalja detaljna istraživanja, posebno longitudinalna, potrebna su da bi se razumela suštinska priroda ovih veza. U svakom slučaju, zdravstveni radnici treba da skrenu pažnju javnosti, posebno mlađoj populaciji, na potrebu za ograničavanjem upotrebe društvenih mreža.

Acta Medica Medianae 2021;60(1):28-37.

Ključne reči: onlajn društvene mreže, zavisnost, depresija, anksioznost 